\title{
PENGARUH MAKROEKONOMI, CAPITAL ADEQUACY RATIO, LOAN TO DEPOSIT RATIO DAN PERTUMBUHAN KREDIT TERHADAP NON PERFORMING LOAN PADA BANK ASING DI INDONESIA PERIODE 2013-2014
}

\author{
MAYA ROSITA, MUSDHOLIFAH \\ Jurusan Manajemen, Fakultas Ekonomi, Universitas Negeri Surabaya, Dosen Manajemen, \\ Fakultas Ekonomi, Universitas Negeri Surabaya \\ Mayarosita1993@gmail.com, Musdholifah@unesa.ac.id
}

\begin{abstract}
The aim of this study was to understand the influence of macroeconomic factors in this research are exchange rate and inflation, while for the internal bank are capital adequacy ratio $(C A R)$, loan to deposit ratio $(L D R)$ and credit growth towards non performing loan (NPL). The data that used is quarterly data from financial statements of Foreign Bank in Indonesia period of 2013 until 2014. Data analysis method used is multiple-regression analysis. The results showed that there was a simultaneous influence of independent variables towards NPL of Foreign Bank in Indonesia. However, partially showed that CAR has a negative influence, the higher capital adequacy ratio, it can serve to accommodate the risk of losses faced by banks due to the increase in non performing loans. LDR has a positif influence, LDR shows expansion of bank loans made to measure current or whether bank intermediary function. LDR which leads to high risk of uncollectible loans to be high which will result in a non performing loans.
\end{abstract}

Keywords: Non Performing Loan (NPL), Macroeconomic, Capital Adequacy Ratio (CAR), Loan to Deposit Ratio (LDR)

\section{Pendahuluan}

Dunia perbankan merupakan salah satu institusi yang sangat berperan dalam bidang perekonomian suatu Negara, khususnya di bidang pembiayaan perekonomian. Bank merupakan bagian dari lembaga keuangan yang memiliki fungsi intermediasi yaitu menghimpun dana dari masyarakat yang kelebihan dana dan menyalurkan dana yang dihimpunnya kepada masyarakat yang kekurangan dana.
Salah satu kegiatan bank yang sangat penting dan utama adalah menyalurkan kredit kepada masyarakat, baik kredit perorangan maupun kredit lembaga atau kredit perusahaan, sehingga pendapatan bank dari kredit yang berupa bunga merupakan sumber utama pendapatan bank. Karena dengan banyaknya fasilitas kredit yang dapat disalurkan kepada masyarakat, tidak menutup kemungkinan bahwa bank tersebut dapat mengalami kesulitan berupa kredit bermasalah yang diproksikan dengan rasio Non Performing 
Loans (NPL) yaitu rasio perbandingan total kredit bermasalah (kurang lancar, diragukan, macet) terhadap total kredit yang disalurkan.

Kredit bermasalah sangat mungkin terjadi karena tidak semua jumlah kredit yang disalurkan kepada masyarakat dalam kondisi sehat, namun ada juga kredit dengan kualitas yang buruk. Jika kredit yang disalurkan mengalami masalah atau bahkan mengalami kredit macet, maka akan berdampak berkurangnya sebagian besar pendapatan bank. Akan tetapi, disisi lain bank tetap harus membayar bunga kepada masyarakat penabung/deposan yang menitipkan dananya. Apapun yang terjadi dengan kredit yang disalurkan, bank tidak dapat menggunakan alasan kredit macet untuk tidak membayar bunga kepada penabung/deposan. Akibatnya, laba bank akan menurun dan apabila kredit bermasalah ini terjadi pada skala kredit yang cukup besar, maka bank akan rugi.

Kredit bermasalah yang besar dalam industri perbankan membawa dampak yang luas. Dari sudut pandang mikro merugikan perkembangan usaha dan kesehatan bank. Sedangkan dari sudut pandang makro, mengingat sebagian dana yang dihimpun bank digunakan untuk menutup kewajiban baik jangka pendek atau jangka panjang. Maka kemampuan bank dalam memberikan kredit baru menjadi berkurang, sehingga menutup kemungkinan calon debitur baru memperoleh fasilitas kredit bank yang berkurang. Dampak lainnya adalah bank akan cenderung terlalu berhati-hati dalam memberikan kredit. Dengan semakin selektif dalam pemberian kredit, berakibat proses pemberian kredit cenderung lama dari prosedur normal dan ekspansi kredit menjadi turun, sehingga mengakibatkan biaya dana dan bunga menjadi lebih tinggi (Soebagio, 2005). Adapun besarnya NPL perkelompok bank menurut Bank Indonesia dapa dilihat pada grafik 1 sebagai berikut:

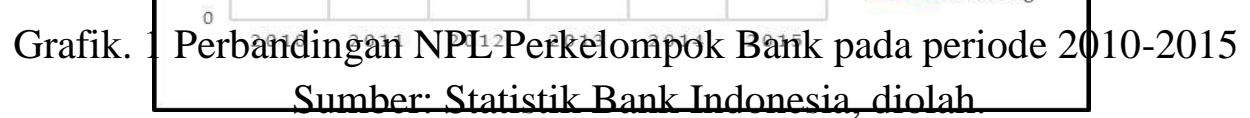

Berdasarkan grafik 1, kelompok bank yang memiliki grafik berbeda adalah kelompok Bank Asing yang ditunjukkan dengan garis warna merah. Karena 


\section{BISMA - Bisnis dan Manajemen -Volume 8 No. 2 Februari 2016}

kelompok Bank Asing sangat aktif merespon setiap kondisi perekonomian di Indonesia dengan pergerakan grafik yang turun dari tahun 2010 hingga tahun 2014. Akan tetapi, pada periode 2013-2014 hanya Bank Asing yang mengalami penurunan disaat kelompok bank yang lain mengalami kenaikan. Sehingga penulis menggunakan periode tersebut dalam penelitiannya. Jumlah dari Bank Asing yang terdaftar dalam Bank Indonesia sebanyak 10 Bank. Menurut Kasmir (2005:35) Bank Asing adalah bank yang kepemilikannya $100 \%$ oleh pihak asing (luar negeri). Bank jenis ini merupakan cabang dari bank yang ada di luar negeri, baik milik swasta asing atau pemerintah asing.

Bank Asing tercatat masih mampu membukukan kinerja positif, meskipun sentimen negatif cenderung mendorong peningkatan kredit macet (NPL). Di tengah tingginya suku bunga acuan Bank Indonesia (BI Rate) serta pembatasan penyaluran kredit konsumsi, justru kredit macetnya bergerak turun. Persentase kredit macet atau NPL Bank Asing mengalami penurunan pada Mei 2013 merupakan prestasi yang sangat bagus (www.medanbisnisdaily.com).

Hal tersebut juga didukung oleh pendapat Kepala BI Wilayah IX Sumut dan Aceh, Difi A Johansyah yang mengatakan, kredit macet Bank Asing yang beroperasi di Sumatra utara memang terus mengalami penurun sejak akhir tahun 2013. Tentu ini sangat baik karena jauh di bawah ketentuan BI yang sebesar $5 \%$. Hal ini sejalan dengan pendapat
Deputi Kepala Perwakilan BI wilayah IV Jatim, Soekowardojo menyatakan penurunan NPL pada triwulan II/2013 disebabkan pertumbuhan kredit yang lebih tinggi dibandingkan pertumbuhan nominal kredit bermasalah. NPL Bank Asing dan Bank Swasta di Jatim memiliki NPL lebih rendah, yaitu masing-masing sebesar $\quad 1,6 \%$ dan $1,66 \%$ (www.portaljatim.com).

Nilai NPL dalam jumlah besar dapat berdampak pada bank yang bersangkutan berupa kerugian bank yaitu kerugian karena tidak diterimanya kembali dana yang telah disalurkan dan pendapatan bunga tidak dapat diterima, artinya bank kehilangan kesempatan mendapat bunga (Ismail, 2010:218). Selain itu NPL juga berdampak pada berkurangnya income dari kredit tersebut yang dapat mengurangi laba bank dan kemampuan memberikan kredit (Dendawijaya, 2001)

Penelitian-penelitian mengenai penyebab terjadinya kredit bermasalah telah dilakukan oleh beberapa peneliti sebelumnya. Penelitian yang dilakukan oleh Soebagio (2005) menyatakan bahwa nilai tukar mata uang berpengaruh positif terhadap terjadinya NPL. Hal ini didukung oleh penelitian Yulita (2014) yang menunjukkan nilai tukar mata uang berpengaruh positif terhadap NPL. Berbeda dengan penelitian yang dilakukan oleh Washington (2014) yang menyatakan bahwa terdapat pengaruh negatif antara nilai tukar dengan NPL. Sedangkan Linda et al., (2015) yang menyatakan bahwa nilai tukar mata uang tidak berpengaruh terhadap NPL. 
Soebagio (2005), Diyanti dan Widyarti (2012), serta Linda et al. (2015) menunjukkan bahwa inflasi berpengaruh positif terhadap terjadinya NPL. Hasil penelitian berbeda ditunjukkan

mengungkapkan bahwa inflasi tidak berpengaruh terhadap NPL.

Diyanti dan Widyarti (2012) menyatakan bahwa capital adequacy bahwa CAR berpengaruh secara negatif terhadap NPL. Berbeda dengan penelitian yang dilakukan oleh Wardoyo dan Rusdiyanti (2009) menyatakan bahwa CAR berpengaruh positif terhadap NPL. Namun, Rahmadani (2015) menyatakan bahwa CAR tidak berpengaruh terhadap NPL.

Ahmad dan Arif (2007), Astrini et al. (2014) serta Rahmadani (2015) menyatakan bahwa Loan to deposit ratio (LDR) berpengaruh secara positif terhadap terjadinya NPL. Soebagio (2005) menunjukan hal berbeda bahwa terdapat pengaruh negatif antara LDR dengan NPL. Namun penelitian tersebut tidak sejalan dengan Diyanti dan Widyarti (2012) yang menyatakan tidak ada hubungan signifikan LDR terhadap NPL.

Yulita (2014) menyatakan bahwa pertumbuhan kredit berpengaruh negatif terhadap terjadinya NPL. Hasil penelitian ini berbeda dengan penelitian Louzis et al. (2010) serta Andres dan Bonilla (2012) yang mengemukakan bahwa pertumbuhan kredit tidak berpengaruh terhadap NPL.

Berdasarkan fenomena dan perbedaan dari penelitian terdahulu tentang pengaruh nilai tukar, inflasi,
Washington (2014) mengemukakan bahwa laju inflasi berpengaruh negatif terhadap NPL. Sedangkan Andres dan Bonilla (2012) serta Rahmadani (2015)

ratio (CAR) berpengaruh negatif terhadap NPL. Hasil penelitian ini sejalan dengan hasil penelitian Soebagio (2005) dan Asrtini et al. (2014) yang menyimpulkan CAR, LDR dan pertumbuhan kredit terhadap non performing loan bank asing menarik untuk dikaji lebih jauh. Rumusan masalah dalam penelitian ini adalah bagaimana pengaruh simultan dan parsial nilai tukar mata uang, inflasi, CAR, LDR dan petumbuhan kredit terhadap non performing loan pada bank asing di Indonesia periode 2013-2014

\section{Teori Makroekonomi}

\section{Perkembangan Teori Makroekonomi}

Perbedaan pemikiran mengenai makroekonomi dibedakan atas pandangan Klasik dan pandangan Keynesian dan beberapa pengembangan baru (Sukirno, 2007:20).

Pandangan Klasik

Ekonomi klasik dicetus oleh Adam Smith (1776) dan Keynes (1936) yang mengungkapkan mengenai penentuan tingkat kegiatan ekonomi negara dan penentuan tingkat kesempatan kerja. Menurut ahli ekonomi Klasik, sistem pasar bebas merupakan sistem yang ideal untuk mengatur kegiatan perekonomian. Dalam pandangan klasik disebutkan bahwa suku bunga ditentukan oleh penawaran tabungan masyarakat dan permintaan dana oleh pengusaha untuk membiayai investasi. 


\section{BISMA - Bisnis dan Manajemen -Volume 8 No. 2 Februari 2016}

Pandangan Keynesian

Pandangan Keynesian merupakan kritik atas pandangan klasik yang menyatakan bahwa perekonomian akan selalu mencapai tingkat kesempatan kerja penuh. Menurut pandangan Keynes, tingkat kegiatan dalam perekonomian ditentukan oleh pembelanjaan agregat dan kebijakan pemerintah perlu untuk mengatur perekonomian antara lain untuk mengukuhkan pertumbuhan ekonomi, menjaga kestabilan sektor luar negeri, serta menstabilkan tingkat harga dan mencegah inflasi.

\section{Masalah dan Kebijakan Ekonomi Makro}

Permasalahan ekonomi ditimbulkan akibat kesenjangan antara aggregate supply dan aggregate demand. Aggregate supply merupakan produk nasional yang dihasilkan atau tersedia dalam suatu negara dan siap ditawarkan. Sedangkan aggregate demand merupakan keseluruhan permintaan masyarakat terhadap produk nasional. Masalahmasalah tersebut antara lain masalah pengangguran, masalah inflasi, masalah pertumbuhan ekonomi dan masalah ketidakstabilan neraca pembayaran (Murni, 2006:6).

Untuk mengatasi berbagai masalah ekoonomi makro suatu negara dapat melalui berbagai kebijakan ekonomi makro, antara lain:

Kebijakan fiskal

Merupakan kebijakan pemerintah untuk mengubah dan mengendalikan penerimaan dan pengeluaran pemerintah melalui APBN. Namun, menurut golongan monetaris kebijakan fiskal tidak efektif dalam mempengaruhi kegiatan ekonomi dan menganggap bahwa kebijakan moneter yang paling efektif untuk mempengaruhi kegiatan ekonomi.

Kebijakan moneter

Merupakan kebijakan yang dilakukan bank sentral dalam mengatur dan mengendalikan jumlah uang beredar dan kredit yang pada gilirannya akan mempengaruhi kegiatan ekonomi masyarakat. Kebijakan bank sentral dalam kebijakan moneter bersifat kuantitatif dan kualitatif. Kebijakan moneter bersifat kuantitatif meliputi kebijakan operasi pasar terbuka (menjual atau membeli obligasi pemerintah), kebijakan tingkat diskonto (penetapan tingkat bunga) dan kebijakan cadangan wajib untuk deposito bank dan lembaga keuangan lainnya. Kebijakan moneter bersifat kualitatif meliputi pengawasan kredit secara selektif dan moral suation yaitu menghimbau secara moral kepada masyarakat pengguna jasa bank.

\section{Teori Manajemen Likuiditas Perbankan}

The Shiftability Theory, teori ini beranggapan bahwa likuiditas suatu bank akan lebih terjamin jika bank bersangkutan memiliki asset yang dapat dipindahkan atau dijual secara cepat, seperti Surat Berharga Bank Indonesia (Hasibuhan, 2001:98).

The Anticipated Income theory, Teori ini beranggapan bahwa likuiditas suatu bank dapat dipertahankan jika bank itu merencanakan pembayaran kembali 
utangnya dengan pendapatan di masa yang akan datang (Hasibuhan, 2001:98).

The Commercial Loan Theory, Teori ini memfokuskan pada kondisi aktiva suatu lembaga perbankan yang terdapat di balance sheet dalam usahanya menjaga kondisi likuiditas bank secara stabil (Fahmi, 2015:106).

Theory Doctrine of Assets Shiftability adalah suatu kondisi dimana pasar keuangan sudah berada dalam kondisi yang benar-benar stabil sesuai dengan yang diharapkan dalam artian demand and supply yang masuk ke pasar pasti selalu terserap atau dapat diserap oleh pasar (Fahmi, 2015:106).

The Gentleman Agreement Theory, teori ini beranggapan bahwa suatu bank dalam menjaga likuiditas minimumnya dilakukan dengan membina kerja sama dan tolong-menolong yang saling menguntungkan di antara sesama bank anggota kliring, yaitu dengan cara interbank call money market, dari lending bank kepada borrowing bank (Hasibuhan, 2001:98).

The Liability Management Theory, teori ini beranggapan bahwa suatu bank dalam menjaga likuiditas minimumnya dilakukan dengan cara mempunyai jaringan pinjaman yang cukup banyak, baik dari rekanan maupun call money atau sumber lainnya (Hasibuhan, 2001:98).

\section{Nilai Tukar Mata Uang atau Kurs}

Badar et al. (2013) menjelaskan bahwa kurs adalah tingkat pertukaran satu mata uang dengan satu sama lain. Nilai tukar ditentukan oleh pasar valuta asing yang terus-menerus tetap dibuka selama 24 jam sehari kecuali akhir pekan yang terdiri dari berbagai jenis pedagang mata uang. Nilai tukar mata uang sebagian besar dipengaruhi oleh pertukaran barang modal dan jasa dalam perdagangan internasional. Penurunan mata uang lokal akan menghasilkan barang impor mahal yang menempatkan tekanan untuk membiayai kredit pedagang oleh bank komersial dan risiko kegagalan mengalami peningkatan.

Menurut Hasibuhan (2005:14) kurs adalah perbandingan nilai tukar mata uang suatu negara dengan mata uang negara asing atau perbandingan nilai tukar valuta antarnegara.

\section{Inflasi}

Menurut Kamus Bank Indonesia, inflasi adalah keadaan perekonomian yang ditandai oleh kenaikan harga secara cepat sehingga berdampak pada menurunnya daya beli, sering pula diikuti menurunnya tingkat tabungan dan atau investasi karena meningkatnya konsumsi masyarakat dan hanya sedikit untuk tabungan jangka panjang. Inflasi dapat disebabkan oleh berbagai faktor, antara lain, konsumsi masyarakat yang meningkat, berlebihnya likuiditas di pasar yang memicu konsumsi atau bahkan spekulasi, sampai termasuk juga akibat adanya ketidaklancaran distribusi barang.

Pengukuran inflasi dapat dilakukan dengan Indeks Harga Konsumen (IHK), Bank Indonesia, dan Badan Pusat Statistik (BPS) dengan menggunakan perhitungann IHK untuk mengukur 
BISMA - Bisnis dan Manajemen -Volume 8 No. 2 Februari 2016

tingkat inflasi yang terjadi dalam suatu wilayah.

\section{Capital Adequacy Ratio (CAR)}

Modal yang dimiliki oleh suatu bank pada dasarnya harus cukup untuk menutupi seluruh risiko usaha yang dihadapi oleh bank. Modal bank diwakilkan dengan rasio capital adequacy ratio (CAR). CAR memperlihatkan seberapa besar jumlah seluruh aktiva bank yang mengandung risiko, yang dibiayai dari modal sendiri.

Capital adequacy ratio (CAR) adalah rasio kinerja bank untuk mengukur kecukupan modal yang dimiliki bank untuk menunjang aktiva yang mengandung atau menghasilkan risiko yang dibiayai dari dana modal sendiri atau sumber dana yang berasal dari luar bank (Dendawijaya, 2001:122).

Hasibuhan (2005:58) mengungkapkan bahwa CAR adalah kebutuhan modal minimum bank dihitung berdasarkan aktiva tertimbang menurut risiko (ATMR). Rasio kebutuhan modal dihitung dengan cara membandingkan modal sendiri dengan ATMR. Menurut Peraturan Bank Indonesia No. 15/12/PBI/2013 besarnya CAR perbankan untuk saat ini minimal $8 \%$ dan berlaku hingga sekarang.

\section{Loan to Deposit Ratio (LDR)}

Menurut Simorangkir (2004:147)

Loan to Deposit Ratio merupakan perbandingan antara kredit yang diberikan dengan dana pihak ketiga, termasuk pinjaman yang diterima, tidak termasuk pinjaman sub ordinasi. Rasio ini menggambarkan kemampuan bank membayar kembali penarikan yang dilakukan nasabah deposan dengan mengandalkan kredit yang diberikan sebagai sumber likuiditasnya. Semakin tinggi rasio ini semakin rendah kemampuan likuiditas bank. Darmawi (2011:61) mengungkapkan kalau LDR meningkat, bankir kurang berminat memberikan pinjaman atau investasi, sehingga kredit menjadi sulit dan suku bunga cenderung naik.

Kasmir (2012:225) menyatakan "loan to deposit ratio (LDR) merupakan rasio untuk mengukur komposisi jumlah kredit yang diberikan dibandingkan dengan jumlah dana masyarakat dan modal sendiri yang digunakan”. Menurut Astrini et al. (2014) LDR merupakan rasio keuangan perusahaan perbankan yang digunakan untuk mengukur perbandingan antara kredit yang diberikan pada masyarakat dengan dana yang diterima bank seperti giro, tabungan, deposito dan kewajiban jangka pendek lainnya.

Loan to Deposit Ratio mempunyai peranan yang sangat penting sebagai indikator yang menunjukkan tingkat ekspansi kredit yang dilakukan bank sehingga LDR dapat juga digunakan untuk mengukur berjalan tidaknya suatu fungsi intermediasi bank. Besarnya loan to deposit ratio menurut Peraturan Bank Indonesia maksimum adalah $92 \%$ dengan batas minimum $78 \%$ (PBI Nomor 15/7/PBI/2013).

\section{Pertumbuhan Kredit}

Pertumbuhan kredit menujukkan peningkatan atau penurunan jumlah 
seluruh kredit yang dipinjam dari waktu ke waktu (biasanya dalam bentuk persentase). Utari et al. (2012) menyatakan bahwa pertumbuhan kredit yang berlebihan dapat mengancam kestabilan ekonomi makro. Peningkatan kredit khususnya kredit konsumsi dapat memicu pertumbuhan permintaan aggregat diatas output potensial yang mengakibatkan perekonomian memanas.

Selama periode ekspansi, sektor perbankan cenderung memiliki ekspektasi yang terlalu optimis pada kemampuan membayar nasabah dan akibatnya kurang hati-hati dalam memberikan kredit kepada golongan beresiko tinggi. Sebagai akibatnya terjadi penumpukan pinjaman yang berpotensi menjadi bad loans.

Pertumbuhan kredit merupakan pertumbuhan total kredit yang diberikan kepada pihak ketiga (tidak termasuk kredit kepada bank lain). Pertumbuhan kredit dihitung dengan cara mengurangi total kredit pada periode tertentu dengan total kredit pada periode sebelumnya, kemudian dibagi dengan total kredit pada periode sebelumnya.

\section{Non Performing Loan (NPL)}

Menurut Kamus Bank Indonesia, Non Performing loan (NPL) adalah kredit bermasalah yang terdiri dari kredit yang berklasifikasi kurang lancar, diragukan dan macet. Linda et al. (2015) berpendapat bahwa salah satu faktor yang menunjukan peningkatan performance dari sebuah bank adalah kemampuan manajemen bank dalam mengelola kredit macet. Semakin rendah kredit macet menunjukan efektifitas bank dalam mengalokasikan dana kredit akan semakin baik. Salah satu rasio yang dapat dijadikan alat untuk mengukur kredit macet adalah Non Performing Loan (NPL). Non Performing Loan merupakan rasio yang menunjukkan seberapa lancar atau macet proses pengembalian kredit yang dilaksanakan oleh nasabah, jika telah menunjukan indikator tidak lancar atau macet tentu nilai NPL mengalami peningkatan. Keadaan tersebut tentu memberikan dampak buruk bagi bank.

Bank Indonesia sebagai otoritas moneter menetapkan tingkat kesehatan setiap bank harus memiliki rasio kredit bermasalah secara neto kurang dari dari 5\% dari total kredit (Peraturan Bank Indonesia Nomor 15/2/PBI/2013).

\section{Pengaruh Nilai Tukar Mata Uang} terhadap NPL

Nilai tukar adalah harga mata uang satu negara dalam satuan mata uang lainnya yang biasa disebut dengan reference currency (Yulita, 2014). Berbagai masalah yang timbul jika suatu negara tidak bisa menjaga kestabilan kurs valuta asingnya. Dalam teori makroekonomi dijelaskan bahwa nilai impor yang lebih tinggi dari nilai ekspor akan menimbulkan beberapa masalah dalam suatu negara. Salah satunya menurunkan nilai mata uang domestik. Hal ini menyebabkan harga barang impor semakin mahal dan inflasi akan meningkat. Kegiatan impor yang berlebihan menyebabkan berkurangnya pembelanjaan barang produksi dalam negeri yang berdampak pada menurunnya 
BISMA - Bisnis dan Manajemen -Volume 8 No. 2 Februari 2016

pendapatan produsen lokal. Sehingga perusahaan lokal mengalami kesulitan untuk membayar kembali kreditnya dan rasio NPL memiliki kemungkinan mengalami peningkatan.

Menurut Soebagio (2005) hasil penelitian menunjukkan bahwa faktor nilai tukar semakin besar pengaruhnya terhadap debitur yang meminjam kredit dalam mata uang asing dan memasarkan produk mereka di dalam negeri dengan harga dalam mata uang nasional. Hal ini menyebabkan pembayaran kembali kredit meningkat sampai diluar batas debitur untuk memikulnya.

Wikutama, 2010 (dalam Yulita, 2014) menjelaskan bahwa depresiasi home currency memberikan dampak terhadap pinjaman dalam valuta asing karena nilai pinjaman meningkat secara relatif sesuai dengan penurunan tersebut. Peningkatan jumlah kewajiban akan mengakibatkan penurunan kemampuan debitur dalam menyelesaikan pinjaman, bahkan dalam banyak kasus mengakibatkan peningkatkan NPL.

\section{Pengaruh Inflasi terhadap NPL}

Kebijakan ekonomi makro dilakukan untuk mengatasi masalah-masalah ekonomi salah satunya untuk mengatasi masalah inflasi. Menurut Martono dan Harjito (2008) inflasi akan mempengaruhi kegiatan ekonomi baik secara makro maupun mikro termasuk kegiatan investasi. Inflasi juga menyebabkan penurunan daya beli masyarakat yang berakibat pada penurunan penjualan. Penurunan penjualan yang terjadi dapat menurunkan return perusahaan.
Penurunan return yang terjadi akan mempengaruhi kemampuan perusahaan dalam membayar angsuran kredit. Pembayaran angsuran yang semakin tidak tepat menimbulkan kualitas kredit semakin buruk bahkan terjadi kredit macet (Taswan, 2006) sehingga memungkinkan meningkatnya angka Non-Performing Loan.

Handayani (2009) dalam Rahmadani (2015) menyebutkan bahwa Inflasi sebagai indikator dalam kondisi perekonomian yang terjadi akibat kenaikan harga secara bersama-sama yang menyebabkan demand mengalami penurunan. Seiring dengan penurunan tersebut, daya beli masyarakat juga ikut menurun sehingga menurunkan penjualan suatu perusahaan. Hal ini disinyalir dapat menurunkan laba perusahaan tersebut. Oleh karena itu, perusahaan mengalami kesulitan dalam membayar kewajibannya di bank. Pembayaran kewajiban yang semakin tidak tepat jatuh temponya akan menimbulkan kualitas kredit bank semakin memburuk bahkan terjadi kredit macet sehingga meningkatkan angka kredit bermasalah.

\section{Pengaruh CAR terhadap NPL}

CAR adalah rasio kecukupan modal yang berfungsi menampung risiko kerugian yang kemungkinan dihadapi oleh bank. CAR merupakan salah satu rasio untuk mengukur likuiditas ditinjau dari sisi modal bank itu sendiri. Menurut Commercial Loan Theory yang memfokuskan pada kondisi aktiva suatu lembaga perbankan yang terdapat di balance sheet dalam usahanya menjaga 
kondisi likuiditas bank secara stabil. Besar kecilnya dana yang dimiliki bank dapat memberikan keuntungan maupun dapat menimbulkan resiko yang harus ditanggung bank. Apabila CAR naik, bisa disebabkan karena modal yang dimiliki meningkat atau nilai ATMR menurun. Pada saat ATMR turun, menandakan bahwa risiko kredit yang ditanggung akan semakin kecil. Karena dimbangi dengan kecukupan modal yang dimiliki maka berdampak pada likuiditas bank yang menjadi stabil.

Semakin tinggi CAR maka semakin baik kemampuan modal bank tersebut untuk menanggung risiko dari setiap kredit atau aktiva produktif yang berisiko dengan menggunakan besarnya cadangan dana yang diperoleh dari perbandingan modal dan aktiva tertimbang menurut risiko. Dalam penelitian Diyanti dan Widyarti (2012) menunjukkan bahwa semakin besar jumlah modal yang dimiliki suatu bank maka akan semakin kecil peluang terjadinya NPL. Semakin tinggi rasio kecukupan modal maka akan dapat berfungsi untuk menampung risiko kerugian yang dihadapi oleh bank karena peningkatan kredit bermasalah.

\section{Pengaruh LDR terhadap NPL}

Fungsi intermediasi perbankan dapat diinterpretasikan melalui Loan to Deposit Ratio (LDR) bank yang bersangkutan. Sumber pendapatan utama bank berasal dari penyaluran kredit. Bank selalu merencanakan pembayaran kembali utangnya untuk pendapatan di masa yang akan datang untuk menjaga likuiditasnya (The anticipated income theory). Rasio
LDR menggambarkan kemampuan bank membayar kembali penarikan yang dilakukan nasabah deposan dengan mengandalkan kredit yang diberikan sebagai sumber likuiditasnya.

Astrini et al. (2014) mengindikasikan bahwa semakin tinggi rasio LDR maka akan menyebabkan meningkatnya rasio NPL yang terjadi pada bank. Karena apabila bank memiliki LDR yang tinggi, maka bank akan mempunyai risiko tidak tertagihnya pinjaman yang tinggi yang nantinya akan mengakibatkan terjadinya kredit bermasalah dan bank akan mengalami kerugian.

\section{Pengaruh Pertumbuhan kredit terhadap NPL}

Dalam instabilitas sistem keuangan selain mempengaruhi likuiditas perbankan juga mendorong terjadinya peningkatan kredit bermasalah, sehingga mengakibatkan perlambatan pertumbuhan kredit maupun pembiayaan lainnya. Karenanya perbankan harus semakin selektif dalam penyaluran kreditnya (Haryati, 2009).

Menurut teori likuiditas (The liability Management Theory) beranggapan bahwa suatu bank dalam menjaga likuiditas minimumnya dilakukan dengan cara mempunyai jaringan pinjaman yang cukup banyak. Sebagai akibatnya terjadi penumpukan pinjaman yang berpotensi menjadi bad loans (Utari et al, 2012). Soebagio (2005) menjelaskan bahwa bank yang memiliki pertumbuhan kredit lebih tinggi cenderung memiliki kualitas portofolio kredit lebih rendah. Hal ini menunjukan bahwa laju pemberian kredit 
tidak secara seimbang diikuti kemampuan bank dalam menilai kredit. Kemungkinan lainnya adalah ketersediaan jumlah dana yang lebih besar mengakibatkan bank memasuki pasar yang bukan merupakan core competence-nya. Akibatnya, lebih banyak kredit yang disalurkan secara tidak berhati-hati. Utari et al. (2012) mengungkapkan bahwa semakin meningkatnya NPL maka keinginan bank memberikan kredit akan menurun.

\section{Hipotesis}

Berdasarkan hubungan antara tujuan penelitian serta kerangka berfikir terhadap rumusan masalah penelitian ini, maka hipotesis yang diajukan adalah sebagai berikut:

H1 : Diduga nilai tukar mata uang, inflasi, capital adequacy ratio, loan to deposit ratio dan pertumbuhan kredit berpengaruh terhadap non performing loan pada Bank Asing di Indonesia periode 2013-2014 secara bersama-sama.

H2 : Diduga nilai tukar mata uang berpengaruh positif terhadap non performing loan pada Bank Asing di Indonesia periode 2013-2014.

H3 : Diduga inflasi berpengaruh positif terhadap non performing loan pada Bank Asing di Indonesia periode 2013-2014.

H4 : Diduga capital adequacy ratio berpengaruh negatif terhadap laporan triwulanan tahun 2013-2014. Data tesebut diperoleh dari situs resmi Bank Indonesia (www.bi.go.id), Otoritas non performing loan pada Bank Asing di Indonesia periode 2013-2014.

H5 : Diduga loan to deposit ratio berpengaruh positif terhadap non performing loan pada Bank Asing di Indonesia periode 2013-2014.

H6 : Diduga pertumbuhan kredit berpengaruh positif terhadap non performing loan pada Bank Asing di Indonesia periode 2013-2014.

\section{METODE PENELITIAN}

Jenis penelitian yang digunakan adalah kausalitas. Menurut Kuncoro (2009:87-90), penelitian kausalitas adalah penelitian yang bertujuan untuk memperoleh pengujian yang tepat dalam menarik kesimpulan hubungan sebabakibat antar variabel. Penelitian ini bertujuan mendapatkan bukti atas hubungan sebab-akibat antara variabel Nilai Tukar Mata Uang, Inflasi, Capital Adequacy Ratio, Loan to Deposite Ratio dan Pertumbuhan Kredit terhadap Non Performing Loan pada Bank Asing.

Penelitian ini menggunakan jenis data kuantitatif berbentuk angka dengan sumber data sekunder yang berupa data

Jasa Keuangan (OJK) serta dokumentasi data statistik seperti Badan Pusat Statistik Indonesia (www.bps.go.id). 
Populasi yang digunakan dalam penelitian ini adalah seluruh Bank Asing yang terdaftar di Bank Indonesia selama periode 2013-2014 berjumlah 10 bank. Sehingga sampel yang digunakan dalam penelitian ini merupakan sampel jenuh karena semua anggota populasi digunakan sebagai sampel.

Variabel yang digunakan dalam penelitian ini terdiri atas variable dependen dan variable independen. Variabel dependen dalam penelitian ini yaitu non performing loan (NPL) sedangkan variable independen dapam penelitian ini yaitu Nilai Tukar Mata Uang, Inflasi, Capital Adequacy Ratio, Loan to Deposite Ratio dan Pertumbuhan Kredit.

\section{Definisi Operasional \\ NPL}

Berdasarkan Surat Edaran Bank Indonesia Nomor 15/35/DPAU tanggal 23 Agustus 2013 Rasio NPL didefinisikan sebagai perbandingan kredit bermasalah (kredit dengan kualitas kurang lancar, diragukan dan macet) terhadap total kredit.

NPL $=\underline{\text { Total Kredit Bermasalah }} \times 100 \%$ Total Kredit

\section{Nilai Tukar Mata Uang}

Nilai tukar adalah tingkat dimana negara-negara melakukan pertukaran mata uang di pasar dunia. Dalam penelitan ini menggunakan mata uang IDR (Indonesian Rupiah) sebagai mata uang domestik dengan USD (United State Dollar) sebagai mata uang asing. Selanjutnya data yang digunakan adalah kurs tengah Bank Indonesia.

$$
\text { Kurs }=\frac{\text { Kurs }_{t}-\text { Kurs }_{t-1}}{\text { Kurs }_{t-1}}
$$

\section{Inflasi}

Inflasi menggambarkan turunnya nilai uang dalam perekonomian Indonesia sebagai akibat naiknya harga barang dan jasa yang lebih banyak dibandingkan jumlah barang atau jasa yang tersedia (Soebagio, 2005). Menurut Murni (2009:35) rumus laju inflasi:

$$
\text { Laju Inflasi }=\frac{\mathrm{IHK}_{\mathrm{t}}-\mathrm{IHK}_{\mathrm{t}-1}}{\mathrm{IHKt}-1} \times 100 \%
$$

$\mathrm{IHK}_{\mathrm{t}}=$ Indeks Harga Konsumen tahun t $\mathrm{IHK}_{\mathrm{t}-1}=$ Indeks Harga Konsumen tahun sebelumnya

CAR

Rasio kebutuhan modal dihitung dengan cara membandingkan modal sendiri dengan Aktiva Tertimbang Menurut Risiko (Hasibuhan, 2005:58).

$$
\mathrm{CAR}=\frac{\text { Modal }}{\mathrm{ATMR}} \times 100 \%
$$

\section{LDR}

Rasio ini menggambarkan kemampuan bank membayar kembali penarikan yang dilakukan nasabah deposan dengan mengandalkan kredit yang diberikan sebagai sumber likuiditasnya (Simorangkir, 2004:147).

$$
\text { LDR }=\frac{\text { Total Kredit }}{\text { Total Dana Pihak Ketiga }} \times 100 \%
$$

\section{Pertumbuhan Kredit}

Menurut Yulita (2014) dalam penelitiannya mendefinisikan bahwa pertumbuhan kredit merupakan pertumbuhan total kredit yang diberikan kepada pihak ketiga (tidak termasuk kredit kepada bank lain). 
BISMA - Bisnis dan Manajemen -Volume 8 No. 2 Februari 2016

Pertumbuhan Kredit $=\frac{\text { Total Kredit }_{\mathrm{t}}-\text { Total Kredit }_{\mathrm{t}-1}}{\text { Total Kredit }_{\mathrm{t}-1}}$

pada penelitian ini adalah analisis regresi linier berganda yang digunakan untuk menguji pengaruh nilai tukar mata uang

\section{Teknik Analisis Data}

Teknik analisis data yang bersifat kuantitatif dalam penelitian ini menggunakan analisis regresi linier berganda. Tahap pertama yang dilakukan adalah menghitung nilai tukar mata uang (kurs), inflasi, capital adequacy ratio, loan to deposite ratio, pertumbuhan kredit dan non performing loan (NPL) dari data yang telah dikumpulkan. Adapun tahap analisis selanjutnya yaitu dengan cara melakukan analisis asumsi klasik.

Analisis asumsi klasik terdiri atas: (1) uji normalitas, (2) uji heteroskedastisitas, (3) uji multikolinieritas dan (4) uji autokorelasi. Setelah dilakukan uji asumsi klasik, uji selanjutnya yang digunakan (kurs), inflasi, capital adequacy ratio, loan to deposite ratio dan pertumbuhan kredit terhadap non performing loan.

Pengujian Hipotesis mengenai pengaruh variable bebas terhadap variable terikat menerapkan uji $\mathrm{F}$ dan uji $\mathrm{t}$ statistik. Kriteria pengujian yang digunakan menurut Ghozali (2013:98) yakni $\mathrm{H}_{0}$ diterima dan $\mathrm{H}_{\mathrm{a}}$ ditolak apabila nilai signifikansi $>0,05$. Artinya variabel bebas tidak berpengaruh terhadap variabel terikat. $\mathrm{H}_{\mathrm{a}}$ diterima dan $\mathrm{H}_{0}$ ditolak apabila nilai signifikansi $<0,05$. Artinya variabel bebas berpengaruh secara signifikan terhadap variabel terikaT

\section{HASIL DAN PEMBAHASAN}

\section{Hasil Uji Asumsi Klasik}

Tabel 1. Uji Asumsi Klasik

\begin{tabular}{|c|c|}
\hline KETERANGAN & HASIL \\
\hline Hasil Uji Normalitas & Sig. 0,376 \\
\hline \multicolumn{2}{|l|}{ Hasil Uji Autokorelasi } \\
\hline - Uji Durbin-Watson & $2,2299<2,322<2,6569$ \\
\hline - Uji Run test & Sig. 0,119 \\
\hline Hasil Uji Heteroskedastisitas: & Sig. \\
\hline - Kurs & 0,872 \\
\hline - Inflasi & 0,658 \\
\hline - CAR & 0,154 \\
\hline - LDR & 0,390 \\
\hline - Pertumbuhan Kredit & 0,302 \\
\hline \multicolumn{2}{|l|}{ Dependen Variabel: AbsUt } \\
\hline Hasil Uji Multikolinearitas: & Tolerance \\
\hline
\end{tabular}




\begin{tabular}{lll} 
- Kurs & 0,803 & 1,245 \\
- Inflasi & 0,920 & 1,087 \\
- CAR & 0,641 & 1,561 \\
- LDR & 0,655 & 1,526 \\
- Pertumbuhan Kredit & 0,771 & 1,298 \\
\hline
\end{tabular}

Dependen Variabel: NPL

Sumber: Output SPSS, 2016

Berdasarkan hasil tabel 1 dapat diketahui

nilai Kolmogorov Smirnov 0,912 dan signifikansi 0,376 maka nilai signifikansi lebih besar dari 0,05, sehingga dapat disimpulkan data berdistribusi normal. Hasil uji heteroskedastisitas dengan menggunakan uji Glejser menunjukkan bahwa nilai signifikansi antara variabel independen dengan absolut nilai residual variabel kurs 0,872, variabel inflasi 0,658 , variabel CAR 0,154, variabel LDR 0,390, dan variabel pertumbuhan kredit 0,302 , dimana lebih dari 0,05, sehingga dapat disimpulkan bahwa dalam model regresi tidak terjadi gejala heteroskedastisitas. Hasil uji multikolinieritas dapat diketahui dengan cara melihat hasil nilai tolerance dan VIF. Nilai tolerance variabel kurs 0,803, variabel inflasi 0,920, variabel CAR 0,641, variabel LDR 0,655, dan variabel pertumbuhan kredit 0,771 , dimana nilai ini berada diatas 0,10 , dan nilai VIF dari variabel kurs 1,245, variabel inflasi 01,087, variabel CAR 1,561, variabel LDR 1,526, dan variabel pertumbuhan kredit 1,298, dimana nilai ini berada dibawah 10 , sehingga dapat disimpulkan bahwa model regresi tidak terdapat gejala multikolinieritas. Hasil uji autokorelasi dengan menggunakan Runs Test menunjukan nilai Asymp. Sig. (2-tailed) 0,119 lebih besar dari 0,05 sehingga hipotesis nol (Ho) diterima dan dapat disimpulkan bahwa dalam model regresi tidak terdapat gejala autokorelasi.

Tahap selanjutnya yaitu menguji model regresi linier berganda. Setelah dilakukan pengujian model regresi linier berganda, maka dilakukan uji hipotesis yang terdiri dari uji $\mathrm{F}$ dan uji t. Hasil analisis regresi linier bergandan dapat dilihat pada tabel 2 berikut:

\section{Hasil Uji Hipotesis}

Tabel 2. Hasil Analisis Regresi Linier Berganda

\begin{tabular}{lll}
\hline KETERANGAN & & HASIL \\
\hline Hasil Uji F & & Sig. 0,027 \\
\hline Hasil Uji t-Statistik: & B & \\
\hline Konstanta & 0,744 & Sig. 0,067 \\
- Kurs & 0,606 & Sig. 0,429 \\
- Inflasi & 0,026 & Sig. 0,817 \\
- CAR & $-0,105$ & Sig. 0,045 \\
- LDR & 0,055 & Sig. 0,007 \\
- Pertumbuhan Kredit & $-0,640$ & Sig. 0,137 \\
\hline Hasil Uji Koefisien & & \\
Determinasi: & & \\
\hline - Adjusted R Square & & 0,153
\end{tabular}


- Koefisien Korelasi (R)

0,488

Dependen Variabel: NPL

Sumber: Outpur SPSS, 2016

Berdasarkan table 2 dapat diketahui bahwa nilai signifikansi pada uji $\mathrm{F}$ lebih kecil daripada nilai alpha $(0,05)$, sehingga $\mathrm{H}_{1}$ diterima dengan kesimpulan bahwa nilai tukar mata uang, inflasi, CAR, LDR dan pertumbuhan kredit berpengaruh terhadap non performing loan secara bersama-sama pada Bank Asing. Sedangkan hasil uji t pada variabel kurs, inflasi dan pertumb uhan kredit diketahui bahwa nilai signifikansi lebih besar daripada alpha $(0,05)$, sehingga dapat disimpulkan bahwa secara parsial kurs, inflasi dan pertumbuhan kredit tidak berpengaruh terhadap non performing loan. Sedangkan pada variabel CAR diketahui nilai signifikansi lebih kecil daripada alpha $(0,05)$ dengan arah hubungan negatif, sehingga dapat disimpulkan bahwa secara parsial CAR berpengaruh negatif terhadap non performing loan. Sementara variabel LDR diketahui nilai signifikansi lebih kecil daripada alpha $(0,05)$ dengan arah hubungan positif, sehingga dapat disimpulkan bahwa secara parsial LDR berpengaruh positif terhadap non performing loan. Maka model regresi yang diperoleh yaitu:

Non Performing Loan $=-0,105 \mathrm{CAR}+$ $0,055 \mathrm{LDR}+\mathrm{e}$

Berdasarkan model di atas terlihat variabel CAR memiliki koefisien regresi bertanda negatif sebesar $-0,105$ yang berarti setiap perubahan satu satuan (1\%) pada CAR, akan mengalami penurunan non performing loan Bank Asing sebesar -0,105 satuan . Dalam hal lain, faktor lain yang mempengaruhi non performing loan dianggap konstan. Untuk variabel LDR terlihat bahwa koefisien regresi untuk variabel LDR sebesar 0,055 yang berarti setiap perubahan satu

satuan (1\%) pada LDR, akan mengalami peningkatan non performing loan Bank Asing sebesar 0,055 satuan. Dalam hal lain, faktor lain yang mempengaruhi non performing loan dianggap konstan.

Hasil tabel 1 dapat diketahui bahwa nilai koefisien determinasi (Adjusted $\mathrm{R}^{2}$ ) sebesar 0,153 berarti variasi variabel independen yaitu kurs, inflasi, capital adequacy ratio, loan to deposit ratio dan pertumbuhan kredit dalam menjelaskan variabel non performing loan pada Bank Asing hanya sebesar 15,3\%, sedangkan sisanya sebesar $84,7 \%$ dijelaskan oleh variabel lain yang tidak diteliti seperti variabel suku bunga, gross domestic product (GDP), dan credit deposit ratio (CDR). Nilai koefisien korelasi (R) sebesar 0,488 menunjukkan bahwa kekuatan hubungan antara variabel independen terhadap variabel dependen hanya sebesar 48,8\% saja dan dapat dikatakan bahwa kemampuan variable independen dalam menjelaskan variabel dependen terbatas.

Hipotesis yang diajukan dalam penelitian ini yaitu kurs, inflasi, LDR dan pertumbuhan kredit berpengaruh positif serta CAR berpengaruh negatif terhadap non performing loan pada Bank Asing di Indonesia periode 2013-2014. Berdasarkan hasil uji $\mathrm{F}$, dapat disimpulkan bahwa variabel independen yaitu kurs, inflasi, CAR, LDR dan pertumbuhan kredit berpengaruh terhadap non performing loan secara bersama-sama pada Bank Asing. Jadi dapat disimpulkan bahwa kelima variabel independen secara bersama-sama dapat digunakan untuk memprediksi non perfroming loan pada Bank Asing. 
Hasil penelitian ini menunjukkan bahwa nilai tukar mata uang (kurs) tidak berpengaruh positif terhadap Non Performing Loan Bank Asing di Indonesia periode 20132014. Hasil ini diperkuat dengan hasil penelitian sebelumnya yang dilakukan oleh Linda et al. (2015) menunjukkan bahwa perubahan kurs tidak begitu dirasakan oleh nasabah, keadaan tersebut terjadi karena perubahan kurs yang relatif terjadi dalam jangka pendek, sehingga situasi tersebut tidak begitu mengganggu bisnis yang dijalankan nasabah, oleh sebab itu perubahan kurs rupiah tidak mempengaruhi kemampuan nasabah untuk membayar tagihan kredit. Dalam teori makro ekonomi, kestabilan nilai tukar mata uang dipengaruhi oleh neraca pembayaran, ketidakseimbangan neraca pembayaran akan menimbulkan berbagai masalah ekonomi misalnya pengangguran dan inflasi (Murni, 2006:16). Untuk mengatasi berbagai masalah ekonomi, pemerintah mengadakan berbagai kebijakan makro seperti kebijakan moneter, kebijakan fiskal, kebijakan di sektor luar negeri dan kebijakan di sektor lain. Sehingga imbas dari ketidakstabilan nilai tukar tidak sampai mempengaruhi perekonomian mesyarakat yang pada saatnya akan berdampak pada non performing loan bank akibat terganggunya pengembalian kredit. Sehingga, hasil penelitian ini tidak mendukung teori yang ada.

Hasil penelitian ini menunjukkan bahwa Inflasi tidak berpengaruh positif terhadap Non Performing Loan Bank Asing di Indonesia periode 2013-2014. Hasil ini diperkuat dengan hasil penelitian sebelumnya yang dilakukan oleh Andres dan Bonilla (2012) dan Rahmadani (2015) menunjukkan bahwa dampak dari tingkat inflasi yang terjadi saat ini tidak akan berpengaruh pada saat ini juga. Sebab membutuhkan timelag yang panjang untuk mempengaruhi kondisi non performing loans bank, sehingga akan berdampak pada periode yang akan datang. Penelitian ini tidak sesuai dengan pandangan Keynes yang menyatakan bahwa kebijakan pemerintah perlu untuk mengatur perekonomian salah satunya adalah mencegah inflasi. Inflasi sebagai indikator dalam kondisi perekonomian yang terjadi akibat kenaikan harga secara bersama-sama yang akan mengakibatkan kenaikan NPL. Namun pada penelitian ini saat terjadi penurunan maupun kenaikan inflasi tidak mempengaruhi secara langsung terjadinya NPL pada bank. Karena peningkatan inflasi tersebut masih tergolong inflasi ringan $(<10 \%)$. Akan tetapi, dengan adanya kebijakan dari Pemerintah bersama Bank Indonesia, perubahan inflasi yang didorong oleh kenaikan harga bahan pangan tersebut masih bisa diatasi dan tidak akan mempengaruhi stabilitas keuangan perbankan terutama kredit bermasalah (NPL). Kebijakan dari Pemerintah bersama Bank Indonesia adalah melakukan diseminasi kebijakan dan edukasi kepada masyarakat dalam rangka mengendalikan ekspektasi inflasi masyarakat, serta menetapkan sasaran inflasi dalam rangka inflation targeting framework. Pengendalian sasaran-sasaran tersebut secara operasional dilakukan dengan operasi pasar terbuka di pasar uang, baik rupiah maupun valuta asing, penetapan tingkat diskonto, penetapan cadangan wajib minimum, dan pengaturan kredit atau pembiayaan (wartaekonomi.co.id). Pengaturan terhadap kredit yang fokus dalam menjaga dan mengawasi pelaksanaan fungsi intermediasi di tiap-tiap bank agar kredit dapat disalurkan sesuai dengan penilaian kredit, pemantauan penggunaan dan jaminan kreditnya. Apabila 


\section{BISMA - Bisnis dan Manajemen -Volume 8 No. 2 Februari 2016}

kebijakan tersebut dapat dilakukan dengan baik oleh pihak perbankan, maka adanya peningkatan inflasi tidak akan memberikan pengaruh pada potensi terjadinya kredit bermasalah (NPL). Hal ini disebabkan nasabah sudah dipantau kemampuannya oleh bank dalam membayar kredit tersebut, sehingga rasio NPL tetap terjaga.

Hasil penelitian ini menunjukkan bahwa Capital adequacy ratio berpengaruh negatif signifikan terhadap Non Performing Loan Bank Asing di Indonesia periode 20132014. Hasil ini diperkuat dengan hasil penelitian sebelumnya yang dilakukan oleh Soebagio (2005) dan Diyanti \& Widyarti (2012) menunjukkan bahwa semakin tinggi rasio kecukupan modal maka akan dapat berfungsi untuk menampung risiko kerugian yang dihadapi oleh bank karena peningkatan kredit bermasalah. Penelitian ini mendukung Commercial Loan Theory bahwa dalam menjaga likuiditasnya, bank harus menjaga kondisi aktiva agar likuiditas bank stabil. Semakin tinggi rasio kecukupan modal maka akan dapat berfungsi untuk menampung risiko kerugian yang dihadapi oleh bank karena peningkatan kredit bermasalah.

Hasil penelitian ini menunjukkan bahwa Loan to deposit ratio berpengaruh positif signifikan terhadap Non Performing Loan Bank Asing di Indonesia periode 20132014. Hasil ini diperkuat dengan hasil penelitian sebelumnya yang dilakukan oleh Ahmad dan Arif (2007) serta Astrini et al. (2014) menyatakan bahwa LDR merupakan indikator yang menunjukkan tingkat ekspansi kredit yang dilakukan bank untuk mengukur berjalan tidaknya suatu fungsi intermediasi bank. Apabila bank memiliki LDR yang tinggi, maka bank akan mempunyai risiko tidak tertagihnya pinjaman yang tinggi yang nantinya akan mengakibatkan terjadinya kredit bermasalah dan bank akan mengalami kerugian. Penelitian ini sesuai dengan Anticipated income theory yang menyatakan bahwa bank selalu merencanakan pembayaran kembali utangnya untuk pendapatan di masa yang akan datang untuk menjaga likuiditasnya. LDR menggambarkan kemampuan bank membayar kembali penarikan yang dilakukan nasabah deposan dengan mengandalkan kredit yang diberikan sebagai sumber likuiditasnya. Dendawijaya (2005) mengatakan bahwa LDR secara penuh akan meningkat dan risiko terjadinya NPL pada bank tersebut semakin tinggi pula. Jadi semakin tinggi LDR sebuah bank, maka semakin tinggi pula peluang munculnya NPL. Hal ini disebabkan karena apabila bank memiliki LDR yang tinggi, maka bank akan mempunyai risiko tidak tertagihnya pinjaman yang tinggi yang nantinya akan mengakibatkan terjadinya kredit bermasalah dan bank akan mengalami kerugian.

Hasil penelitian ini menunjukkan bahwa Pertumbuhan Kredit tidak berpengaruh negatif terhadap Non Performing Loan Bank Asing di Indonesia periode 20132014. Hasil ini diperkuat dengan hasil penelitian sebelumnya yang dilakukan oleh Louzis et al. (2010) dan Andres \& Bonilla (2012) menunjukkan bahwa penyaluran kredit yang baru tidak dapat mempengaruhi Non performing loan, melainkan lebih dipengaruhi oleh pinjaman yang sudah ada. Hasil penelitian berbeda ditunjukkan oleh Yulita (2014) yang menyatakan bahwa pertumbuhan kredit berpengaruh signifikan terhadap non performing loan bank. Penelitian ini tidak sesuai dengan The Liability Management Theory yang beranggapan bahwa suatu bank dalam menjaga likuiditas minimumnya dilakukan dengan cara mempunyai jaringan pinjaman 
yang cukup banyak. Kredit perbankan memiliki peran penting dalam pembiayaan perekonomian nasional dan merupakan motor penggerak pertumbuhan ekonomi. Ketersediaan kredit memungkinkan rumah tangga untuk melakukan konsumsi yang lebih baik dan memungkinkan perusahaan untuk melakukan investasi yang tidak bisa dilakukan dengan dana sendiri sehingga pertumbuhan ekonomi tersebut dapat mendorong pertumbuhan kredit. Sebagai akibatnya terjadi penumpukan pinjaman yang berpotensi menjadi bad loans (Utari et al., 2012). Menurut Louzis et al. (2010) menyebutkan bahwa pinjaman agresif tidak selalu bertepatan dengan pengambilan risiko sembrono yang bukan merupakan core competence-nya.

\section{KESIMPULAN}

Berdasarkan hasil pengolahan data-data penelitian dan pembahasan dapat disimpulkan bahwa nilai tukar mata uang, inflasi, capital adequacy ratio, loan to deposit ratio dan pertumbuhan kredit secara bersama-sama berpengaruh terhadap non performing loan pada Bank Asing di Indonesia periode 20132014. Secara parsial Capital adequacy ratio berpengaruh negatif signifikan terhadap non performing loan dan Loan to deposit ratio berpengaruh positif signifikan terhadap non performing loan. Sedangkan nilai tukar mata uang, Inflasi dan pertumbuhan kredit tidak berpengaruh terhadap non performing loan pada Bank Asing di Indonesia periode 20132014. Disarankan bagi nasabah perbankan dalam menyimpan dananya, hendaknya memperhatikan kondisi bank yang besangkutan yang tercermin dalam rasio-rasio keuangan yang mencerminkan tingkat kesehatan bank seperti non performing loan, capital adequacy ratio, loan to deposit ratio. sehingga dapat mengambil langkah yang benar dalam hal melakukan penyimpanan dana di bank. Disarankan bagi perusahaan perbankan agar bank lebih meningkatkan penyaluran kreditnya dengan memberikan kepercayaan kepada para nasabah untuk tetap menyimpan dananya di bank. Dengan peningkatan CAR, diharapkan laba perusahaan juga akan ikut meningkat. Dan dengan meningkatnya LDR, diharapkan fungsi intermediasi bank dapat berjalan lancar. Serta apabila bank mengeluarkan kredit kepada nasabah, resiko adanya kredit macet (NPL) itu harus lebih diminimalisir dengan peninjauan terlebih dahulu, apakah kredit tersebut layak diberikan atau tidak.

Penelitian ini menunjukkan tiga variabel independen yang tidak berpengaruh terhadap non performing loan, yaitu nilai tukar mata uang, inflasi dan pertumbuhan kredit. Pada penelitian selanjutnya dapat menggunakan proksi lain misalnya, suku bunga, gross domestic product (GDP), credit deposite ratio (CDR) sehingga hasil dari penelitian selanjutnya akan lebih baik.

\section{DAFTAR PUSTAKA}

Ahmad, Nor Hayari \& Mohamed Arif, 2007. Multi-Country Study of Bank Credit Risk Determinants. International Journal of Banking and Finance, Vol. 5 , Issue (http://epublications.bond.edu.au/ijbf/v ol5/iss 1/6/, diakses 19 Oktober 2015)

Andres, Carlos \& Olaya Bonilla. 2012. Macroeconomic Determinants of the Non Performing Loans in Spain and Italy.

(http://www.banrepcultural.org/sites/de fault/files/tesis_olaya_carlos .pdf, diakses 25 November 2015) 


\section{BISMA - Bisnis dan Manajemen -Volume 8 No. 2 Februari 2016}

Astrini, Km Suli, I Wayan Sawendra \& I Ketut Suwarna. 2014. Pengaruh CAR, LDR, Dan Bank Size Terhadap NPL

Pada Lembaga Perbankan Yang Terdaftar Di Bursa Efek Indonesia. EJournal Bisma Universitas Pendidikan Ganesha. Vol. 2, diakses 2 Desember 2015.

Badar, Munib, Atiya Yasmin Javid \& Shaheed Zulfiquar. 2013. Impact of Macro economic forces on Nonperforming loans an empirical study. Elixir International Journal (Online). (www.elixirpublishers.com, diakses 13 Oktober 2015)

Bank Indonesia, 12 November 1998, Surat Edaran Bank Indonesia: SK Direksi BI No.31/147/KEP/DIR.

Dendawijaya, Lukman. 2001. Manajemen Perbankan. Jakarta: Ghalia Indonesia.

Diyanti, Anin \& Widyarti, Endang Tri. 2012. Analisis Pengaruh Faktor Internal Dan Eksternal Terhadap Terjadinya Non Performing Loan (Studi Kasus pada Bank Umum Konvensional yang Menyediakan Layanan Kredit Pemilikan Rumah Periode 2008-2011. Diponegoro Journal of Management (Online), Vol. 1, No. 2, Pg. 290-299. (http://ejournal-

s1.undip.ac.id/index.php/djom, diakses 19 Oktober 2015)

Fahmi, Irham. 2015. Manajemen Perbankan: Konvensional dan Syariah. Jakarta: Mitra Wacana Media.

Ghozali, Imam. 2013. Aplikasi Analisis Multivariate Dengan Program IBM SPSS 21. Cetakan ketujuh. Penerbit: Badan Penerbit Universitas Diponegoro.

Haryati, Sri. 2009. Pertumbuhan Kredit Perbankan di Indonesia: Intermediasi dan Pengaruh Variabel Makro Ekonomi. Jurnal Keuangan dan perbankan. Vol. 13, No. 2, Pg. 299310, diakses 30 Desember 2015.

Hasibuhan, Malayu. 2001. Dasar-Dasar Perbankan. Jakarta: PT. Bumi Aksara.

Hasibuhan, Malayu. 2005. Dasar-Dasar Perbankan. Jakarta: PT. Bumi Aksara.

Ismail. 2010. Akuntansi Bank: Teori dan Aplikasi Dalam Rupiah. Jakarta: Kencana Kasmir.2005. Bank dan Lembaga Keuangan lainnya. Jakarta: Grafindo Persada.

Kasmir. 2012. Analisis Laporan Keuangan. Jakarta: Rajawali Pers.

Kuncoro, Mudrajat. 2009. Metode Riset Untuk Bisnis \& Ekonomi. Edisi Ketiga. Penerbit: Erlangga.

Linda, Muthia Roza, Megawati \& Deflinawati. 2015. Pengaruh Inflasi, Kurs Dan Tingkat Suku Bunga Terhadap Non Performing Loan Pada PT. Bank Tabungan Negara (Persero) Tbk Cabang Padang. Jurnal Pendidikan Ekonomi (Online), Vol.3, No.2. Pg 137-144, diakses 13 Oktober 2015)

Louzis, Dimitrios P, Angelos T Vouldis \& Vasilios L Metaxas. 2010. Macroeconomic And Bank-Specifik Determinants Of Non-Performing Loans In Greece: A Comparative Study Of Mortagage, Business And Consumer Loan Portofolios. Economic Research Departement-Special Studies Division.(http://www.kemerburgaz.edu .tr/images/basi n/science.pdf, diakses 19 Oktober 2015)

Martono, dan Harjito, Agus. 2008. Manajemen Keuangan. Yogyakarta: Ekonisia.

Murni, Asfia. 2006. Ekonomika Makro. Bandung: PT. Refika Aditama. 
Maya Rosita dan Musdholifah - Pengaruh Makroekonomi, Capital Adequacy Ratio...

Murni, Asfia. 2009. Ekonomi Makro. Bandung: PT. Refika Aditama.

Peraturan Bank Indonesia Nomor 15/2/PBI/2013 Tentang Penetapan Status Dan Tindak Lanjut Pengawasan Bank Umum Konvensional.

Peraturan Bank Indonesia Nomor 15/7/PBI/2013 Tentang Giro Wajib Minimum Bank Umum Dalam Rupiah Dan Valuta Asing Bagi Bank Umum Konvensional.

Peraturan Bank Indonesia Nomor 15/12/PBI/2013 Tentang Kewajiban Penyediaan Modal Minimum Bank Umum.

Rahmadani, Dianti. 2015. Analisis Terhadap Tingkat Kredit Macet (Non Performing Loans) Studi Pada Bank Umum Konvensional Periode 20102014. Jurnal Fakultas Ekonomi dan Bisnis Universitas Brawijaya Malang.

Sukirno, Sadono. 2007. Mikro Ekonomi Teori Pengantar. Jakarta: PT. Raja Grafindo Persada.

Wardoyo, Paulus \& Endang Rusdiyanti, 2009. Faktor-Faktor Yang Mempengaruhi Non Performing Loan Bank Perkreditan Rakyat Di Eks Karesidenan Semarang. J. Dinamika Sosbud (Online), Vol. 11, No. 2, Pg. 127-139

(http://journal.usm.ac.id/jurnal/dinamikasosial-budaya/265/detail/, diakses 19 Oktober 2015)

Washington, Gitonga Kariuki. 2014. Effect Of Macroeconomic Variables On Credit Risk In The Kenyan Banking
Simorangkir. 2004. Pengantar Lembaga Keuangan Bank dan Non Bank. Bogor: Ghalia Indonesia.

Soebagio, Hermawan. 2005. Analisis FaktorFaktor Yang Mempengaruhi Terjadinya Non Performing Loan (NPL) Bank Umum Komersial. Tesis Dipublikasikan. Tesis Prodi Sains Akuntansi Program Pasca Sarjana Universitas Diponegoro.

Statistik Indonesia. Badan pusat statistik (Online), (www.bps.go.id), diakses 12 November 2015) Statistik perbankan Indonesia (online), www.bi.go.id, diakses 12 Oktober 2015)

Utari, G A Diah, Trinil Arimurti \& Ina Nurmalia Kurniati. 2012. Pertumbuhan Kredit Optimal. Buletin Ekonomi Moneter dan Perbankan.

System. International Journal of Business and Commerce (Online), Vol. 3, No. 9, Pg. 01-26. (http://www.ijbcnet.com/3-9/IJBC14-3903.pdf, diakses 19 Oktober 2015) Yulita, Anatia. 2014. Analisis Pengaruh Faktor Makroekonomi Terhadap Tingkat Kredit Bermasalah Pada Bank Umum Di Indonesia. Skripsi Dipublikasikan. Skripsi Jurusan Manajemen Program Sarjana Universitas Diponegoro. 